\title{
Production of pepper seedlings with different doses of organic compounds in substrate
}

\author{
Lucas Aparecido Manzani LISBOA ${ }^{*}$, Alan dos Santos CARDOSO², Karem Cristine Pirola NARIMATSU2, \\ Nubia Priscila de Oliveira CRISPIM², Pedro Henrique de Conde de ALMEIDA², \\ Hiago Augusto Amaral SACCO², Leandro Barradas PEREIRA², Carlos Eduardo de Oliveira DIAS² \\ ${ }^{1}$ Faculdade de Ciências Agrárias e Tecnológicas, Universidade Estadual Paulista, Dracena, SP, Brasil. \\ ${ }^{2}$ Fundação Educacional de Andradina, Andradina, SP, Brasil. (ORCID: 0000-0002-5031-7896; 0000-0002-2600-5307; 0000-0002-5496- \\ 5356; 0000-0003-4498-7786; 0000-0002-5269-0790; 0000-0002-1830-0170; 0000-0002-9982-7539) \\ *E-mail: lucas.lisboa@unesp.br (ORCID: 0000-0001-9013-232X)
}

Recebido em 07/05/2019; Aceito em 02/04/2020; Publicado em 24/04/2020.

\begin{abstract}
One of the main responsible attributes for the good quality of seedlings is its cultivation in substrates with a good drainage and nutrients availability. This work aimed to study the production of pepper seedlings with different doses of organic compounds in substrate. The experiment was carried out in August, 2018, at Educational Foundation of Andradina, in Andradina, São Paulo State, Brazil. The experimental design was completely randomized, in a $2 \times 5$ factorial scheme, with two organic substrates: peaty exhausted compound (EC) and coconut fiber compound (CC), in five different concentrations: null $\% ; 25 \% ; 50 \% ; 75 \%$ and $100 \%$, with five repetitions, in total of fifty plots. The increase in the concentration of organic compounds in production of pepper seedlings promoted a greater development. It is recommended using $70 \%$ of peaty exhausted in the composition of substrate to the production of pepper seedlings and using $100 \%$ of coconut fiber in the composition of the substrate to the production of pepper seedlings.
\end{abstract}

Keywords: Capsicum annum L.; nutrition of plants; vegetables.

\section{Produção de mudas de pimentão em diferentes fontes e doses de compostos orgânicos}

\begin{abstract}
RESUMO: Um dos atributos responsáveis pela boa qualidade das mudas é o seu cultivo em substratos com boa drenagem e disponibilidade de nutrientes. O objetivo a produção de mudas de pimentão em diferentes doses de compostos orgânicos no substrato. O experimento foi conduzido durante o mês de agosto de 2018, na Fundação Educacional de Andradina, localizada no município de Andradina, estado de São Paulo. Foi utilizado o delineamento inteiramente casualizado, em esquema fatorial de $2 \times 5$ sendo dois substratos orgânicos, sendo eles: composto exaurido turfoso (EC) e composto com fibras de coco (CC) interagindo com cinco concentrações (C), ou seja: zero \%; 25\%; 50\%; 75\% e 100\% e com cinco repetições, totalizando 50 parcelas ou tubetes plásticos. A elevação na concentração de compostos orgânicos no substrato para produção de mudas de pimentão proporcionou um maior desenvolvimento das plântulas. É recomendada a utilização de $70 \%$ de composto exaurido turfoso na composição do substrato na produção de mudas de pimentão. Pode utilizar a concentração de $100 \%$ o composto com fibra de coco na composição do substrato na produção de mudas de pimentão.

Palavras-chave: Capsicum annuum L.; nutrição de plantas; hortaliça.
\end{abstract}

\section{INTRODUCTION}

Pepper (Capsicum annuum L.) is among the most produced vegetables in Brazilian olericulture (PORTO et al., 2018), its yield has conquered the market, in which new methods of production has been studied in order to increasing the production and facilitating cultivars treatments, demanding high quality seedlings (COSTA et al., 2015).

The success in seedlings productions is linked to good treatments of the cultivars, as well as they are sown (MORTATE et al., 2018). One of the attributes that is responsible for the good quality seedlings, is its cultivation in substrates with a good drainage and nutrients availability, in which alternative sources from organic matter may turns in an alternative to producers (MONTEIRO NETO et al., 2016).

Composting is a suitable technique to nourish soil, with the limiting factor is the interaction between carbon and nitrogen $(\mathrm{C} / \mathrm{N})$, which, in low rate, may negatively influences seedlings development, entailing nutritional deficits. Organics residues are present in the formation of seedlings and work as an alternative to diminish spend with industrial fertilizers (EPELDE et al., 2018), besides they promote better roots systems, decaying the stress after-sowing, once they are directly linked to absorption of nutrients from substrate (ABID et al., 2016).

In general, plants under organic fertilizers display greater development of the aerial part, mainly in new shoots, 
influencing the formation of seedlings (BURNETT et al., 2016). Results prove the exhausted compounds, through the time, release organic substances with high nutrients levels, mainly nitrogen and calcium (LI et al., 2017).

Combination of peaty exhausted compound (EC) or coconut fiber compound (CC) can promote to substrates suitable features to the development of seedlings due to the high concentration of nutrients and physical properties changes, performing a greater water retention and fertility (MEDEIROS et al., 2018). Organic compound found in substrates has an advantage, since it contains a rich microbiota that promotes physiological inducement on synthesis of compounds that act in cultivar's phytosanitary, stimulating the resistance to diseases (CORREIA; MICHEREFF, 2018).

Therefore, this work aimed to study the production of pepper seedlings with different doses of organic compounds in substrate.

\section{MATERIALS E METHODS}

The experiment was carried out in August, 2018, at Educational Foundation of Andradina, in Andradina, São Paulo State, Brazil. The experimental design was completely randomized, in a $2 \times 5$ factorial scheme, with two organic substrates: peaty exhausted compound (EC) and coconut fiber compound (CC), in five different concentrations: null $\% ; 25 \% ; 50 \% ; 75 \%$ and $100 \%$, with five repetitions, in total of fifty plots.

Table 1 brings chemical attributes of soil and as well as organic compounds. After mixing the organic compounds in the soil, a viable seed of Cascadura Ikeda variety was sown at $2 \mathrm{~cm}$-depth in tubes with a volumetric capacity of $0.2 \mathrm{dm}^{3}$.

During the conduction of the experiment, all phytosanitary treatments were performed and the tubes were irrigated whenever necessary, respecting the field capacity.

Thirty days after sowing, the following parameters were set: plant height $(\mathrm{PH})$, by using a millimeter ruler; number of leaves (NL), through direct counting; dry mass of aerial part (DMAP) and dry mass of root (DMR), which were set by drying the humid mass in oven with air circulation and renewal, under a steady $65^{\circ} \mathrm{C}$ temperature, till they reach steady weight.

Abaxial epidermal surface of the collected fragments were printed using cyanoacrylate ester, in order to set the stomatal functionality of abaxial face (SF) and stomatal density of abaxial surface (SD) (CARLQUIST, 1975; CASTRO et al., 2009). In all the features, ten measurements were carried out per slide. Plots were represented by the average value of measurements of each criteria.

Table 1. Chemical atributes of soil and organic compounds.

Tabela 1. Atributos químicos do solo e dos compostos orgânicos.

\begin{tabular}{|c|c|c|c|c|c|c|c|c|c|c|c|c|c|c|c|c|c|}
\hline & $\mathrm{pH}$ & $\mathrm{MO}$ & $\mathrm{P}$ & K & $\mathrm{Ca}$ & $\mathrm{Mg}$ & $\mathrm{H}+\mathrm{Al}$ & $\mathrm{Al}$ & SB & CTC & $\mathrm{V} \%$ & $\mathrm{~m} \%$ & B & $\mathrm{Cu}$ & $\mathrm{Fe}$ & $\mathrm{Mn}$ & $\mathrm{Zn}$ \\
\hline & $\mathrm{CaCl}_{2}$ & $\mathrm{~g} \mathrm{dm}^{-3}$ & $\mathrm{mg} \mathrm{dm^{-3 }}$ & & - & - & $\mathrm{mm}$ & $c \mathrm{dm}$ & $3---$ & 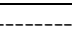 & & & \multicolumn{5}{|c|}{------- $\mathrm{mg} \mathrm{dm}{ }^{-3}$------- } \\
\hline \multirow[t]{4}{*}{ S } & 5.9 & 11 & 21 & 2.0 & 19 & 7 & 15 & 0 & 28 & 43 & 65 & 0 & 0.21 & 1 & 25 & 9 & 3.4 \\
\hline & & & $\mathrm{N}$ & & & & K & & & & & \multicolumn{2}{|c|}{ S } & & & & \\
\hline & $\mathrm{CC}$ & & 4.6 & & & & 6.3 & & & & & \multicolumn{2}{|c|}{2.9} & & & & \\
\hline & EC & & 17.2 & & & & 16.3 & & .2 & & & \multicolumn{2}{|c|}{21.0} & & & & \\
\hline
\end{tabular}

SB: Sum of bases; V\%: Saturation per bases; $\mathrm{m} \%$ : Saturation per alumínio. S: Soil; CC= Coconut compound and EC: Exhausted compound.

All variables were submitted to the $\mathrm{F}$ test $(\mathrm{p}<; 0,05)$ and analysis of regression were applied in concentrations of organic compounds, in which their standards were tested: linear, quadratic and cubic (BANZATTO; KRONKA, 2013). Organic substrates were submitted to Turkey Test, at 5\% probability. Pearson's correlation was performed. Statistic program Assitat 7.7 was used (SILVA; AZEVEDO, 2016).

\section{RESULTS}

Exhausted compound promoted a plant height $(\mathrm{PH})$ around $11,12 \%$ greater as compared to coconut fiber (Table 2). Similarly, exhausted promoted a higher number of leaves and dry mass of aerial part, respectively, $17,6 \%$ and $30 \%$ as compared to coconut fiber.

Dry mass of root did not display significant difference (Table 2), but an effect was pointed between the organic compounds in relation to stomata density of abaxial surface of peppers, in which coconut fiber presented a value $26,37 \%$ higher. Regarding stomata functionality, no significant difference was observed (Table 2).

By considering the concentration of organic substrate to production of peppers seedlings, a linear positive response was observed to the use of coconut fiber, while the exhausted compound presented a quadratic response to the parameter plant height (Table 3).
The peak of plant height in exhausted compound was around $70 \%$ in the composition of substrate (Figure 1). Similarly, in the parameter number of leaves, a positive linear response to the coconut fiber compound and an ascending quadratic response to exhausted compound were observed, in which it presented maximum value of concentration, around $70 \%$, when mixed with substrate (Figure 2). Linear responses were observed in the concentration of organic compounds in substrates of coconut fiber and exhausted compound regarding dry mass of aerial part (Figure 3).

By considering the concentration of organic compounds in substrate, linear positive responses were observed in both studied compounds regarding dry mass of root (Figure 4).

To the morphological parameter stomatal density of abaxial surfasse of peppers, doses of organic compounds in substrate linearly influenced (Table 3). A significant differece was not observed between the organic compounds to the parameter stomatal density (Table 2), however linear negative effects were observed as the concentration of organic compound in substrate increased.

Coconut fiber presented a quadratic negative response to the parameter stomatal density of abaxial surface, in which the deepest point was detected at arround $46,6 \%$ of concentration in substrate (Figure 6). Some parameters presented correlation to each other, as Table 4 shows. 
Table 2. Average values of plant height; number of leaves; dry mass of shoot and root; stomatal density and stomatal functionality of pepper seedlings in sources of organic compounds for the production of seedlings.

Tabela 2. Valores médios de altura de planta; número de folhas; massa seca da parte aérea e de raiz; densidade estomática e funcionalidade estomática do pimentão quando cultivado em fontes de compostos orgânicos para a produção de mudas.

\begin{tabular}{|c|c|c|c|c|c|c|}
\hline $\mathrm{OC}$ & $\begin{array}{l}\mathrm{PH} \\
(\mathrm{cm})\end{array}$ & NL & DMAP (g) & $\begin{array}{l}\text { DMR } \\
(\mathrm{g})\end{array}$ & $\mathrm{SD}\left(\mathrm{n}^{\circ} \mathrm{S} / \mathrm{mm}^{2}\right)$ & SF \\
\hline $\mathrm{CC}$ & $11.82 \mathrm{~b}$ & $5.15 b$ & $0.0345 b$ & $0.0102 \mathrm{a}$ & $126.62 \mathrm{a}$ & $3.07 \mathrm{a}$ \\
\hline $\mathrm{EC}$ & $13.30 \mathrm{a}$ & $6.25 \mathrm{a}$ & $0.0490 \mathrm{a}$ & $0.0093 \mathrm{a}$ & $93.22 \mathrm{~b}$ & $3.23 \mathrm{a}$ \\
\hline DMS & 1.17 & 0.65 & $0.0090^{-}$ & 0.0017 & 19.60 & 0.33 \\
\hline CV\% & 14.45 & 17.76 & 33.34 & 27.35 & 27.48 & 16.55 \\
\hline GA & 12.56 & 5.70 & 0.0417 & 0.0097 & 109.92 & 3.15 \\
\hline $\mathrm{fOC}$ & $6.60^{*}$ & $11.79 * *$ & $10.79^{* *}$ & $1.06 \mathrm{Ns}$ & $12.22^{* *}$ & $0.99 \mathrm{Ns}$ \\
\hline $\mathrm{f} C$ & $7.04 * *$ & $9.05^{* *}$ & $6.32^{* *}$ & $19.96^{* *}$ & $6.63 * *$ & $4.20^{* *}$ \\
\hline f OCXC & $3.09 \%$ & $2.84 *$ & $3.82{ }^{*}$ & $14.11 * *$ & $3.85^{*}$ & $1.77 \mathrm{Ns}$ \\
\hline
\end{tabular}

OC: organic compound; CC: coconut fiber; EC: exhausted compound; MSD: maximum significant difference; CV: coefficient of variation; GA: general average; $\mathrm{f}: \mathrm{f}$ value in analysis of variance; $\mathrm{C}=$ concen; Ns- $\mathrm{p}>=0.05 ; * 0.01=<\mathrm{p}<0.05 ; * * \mathrm{p}<0.01$. The averages in the column followed by the same letter do not statistically differ from each other. The Tukey test was applied at a $5 \%$ probability level.

Table 3 Variance analysis of the regressions of concentrations of organic compounds present in the substrates in production of pepper, with tested standards: linear, quadratic and cubic.

Tabela 3. Análise de variância das regresses das concentrações de compostos orgânicos presentes nos substratos para a produção de mudas de pimentão, onde foram testados os modelos: linear, quadrático e cúbico.

\begin{tabular}{|c|c|c|c|c|c|c|c|c|}
\hline \multicolumn{9}{|c|}{ Middle Square } \\
\hline & $\mathrm{FV}$ & GL & PH (cm) & NL & DMAP $(\mathrm{g})$ & DMR (g) & $\mathrm{SD}\left(\mathrm{n}^{\circ} \mathrm{S} / \mathrm{mm}^{2}\right)$ & $\mathrm{SF}$ \\
\hline \multirow{3}{*}{$\mathrm{CC}$} & $\%$ & 4 & 50,625 & 8,100 & 0,0013 & 0,0005 & 14440,00 & 2,2480 \\
\hline & Residue & 16 & 4,853 & 0,897 & 0,0002 & 0,000007 & 1606,994 & 0,3489 \\
\hline & Regression & 1. & $L^{* *}$ & $L^{* *}$ & $L^{*}$ & $L^{* *}$ & $\mathrm{~L}^{* *}$ & $Q^{*}$ \\
\hline \multirow{3}{*}{$\mathrm{EC}$} & $\%$ & 4 & 36,160 & 15,017 & 0,0030 & 0,0001 & 4483,806 & 0,0005 \\
\hline & Residue & 16 & 1,713 & 1,006 & 0,0001 & 0,00001 & 332,467 & 0,2101 \\
\hline & Regression & 1 & $\mathrm{Q}^{* *}$ & $\mathrm{Q}^{* *}$ & $\mathrm{~L}^{* *}$ & $\mathrm{~L}^{*}$ & $\mathrm{~L}^{* *}$ & Ns \\
\hline
\end{tabular}

$\mathrm{PH}$ - plant height; NL - number leaf; DMAP - Dry mass of the air part; S: Stomata; SD - Stomata density and SF - Stomata functionality.

Table 4. $R$ values in the Pearson's correlations between the analyzed variables of the pepper seedlings when cultivated at different doses and sources of organic compounds.

Tabela 4. Valores do $r$ das correlações de Pearson entre as variáveis analisadas das plântulas de pimentão quando cultivadas em diferentes doses e fontes de compostos orgânicos.

\begin{tabular}{llllll}
\hline & PH & NL & DMAP & DMR & SD \\
\hline NL & $0.74724^{* *}$ & & & & \\
DMAP & $0.57067^{* *}$ & $0.62660^{* *}$ & & & \\
DMR & $0.68438^{* *}$ & $0.64708^{* *}$ & $0.48694^{* *}$ & $-0.5102^{* *}$ & $-0.1768 \mathrm{Ns}$ \\
SD & $-0.39233^{*}$ & $-0.3029 \mathrm{Ns}$ & $-0.36968^{*}$ & $0.22748 \mathrm{Ns}$ & \\
SF & $0.16986 \mathrm{Ns}$ & $0.21052 \mathrm{Ns}$ & $0.09056 \mathrm{Ns}$ & S
\end{tabular}

Ns-p $>=0.05 ; * 0.01=<\mathrm{p}<0.05 ; * * \mathrm{p}<0.01 ; \mathrm{PH}-$ plant height; NL - number leaf; DMAP - Dry mass of the air part; S: Stomata; SD - Stomata density and $\mathrm{SF}$ - Stomata functionality.

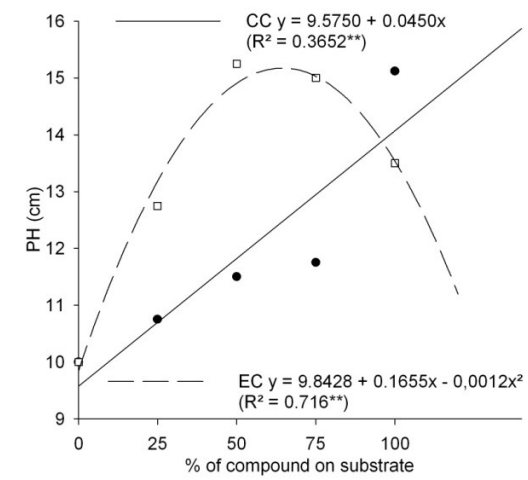

Figure 1. Plant height $(\mathrm{PH})$ of peppers sown in substrates with different organic compounds to production of seedlings. $\mathrm{CC}=$ Coconut compound; EC= Exhausted compound. Andradina, 2018 Figura 1. Altura de planta (PH) do pimentão cultivado em substratos com diferentes compostos orgânicos para produção de mudas. CC= Composto de coco; EC= Composto exaurido. Andradina, 2018.

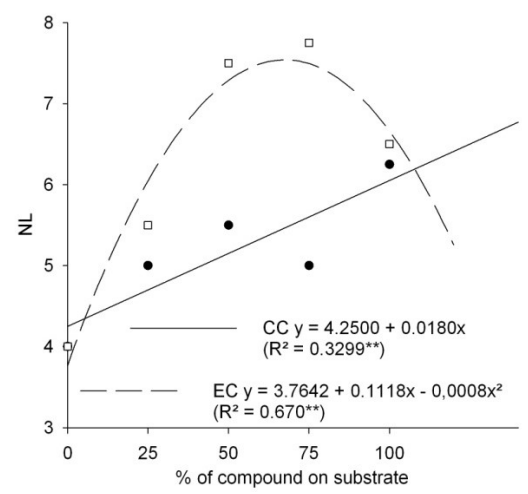

Figure 2. Number of leaf (NL) of peppers sown in substrates with different organic compounds to production of seedlings. $\mathrm{CC}=$ Coconut compound; EC= Exhausted compound. Andradina, 2018. Figura 2. Número de folhas (NL) do pimentão cultivado em substratos com diferentes compostos orgânicos para produção de 
mudas. $\mathrm{CC}=$ Composto de coco; $\mathrm{EC}=$ Composto exaurido. Andradina, 2018.

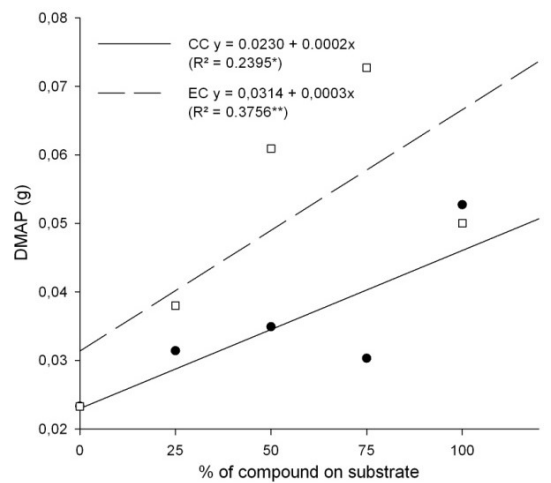

Figure 3. Dry mass of aerial part (DMAP) of peppers sown in substrates with different organic compounds to production of seedlings. $\mathrm{CC}=$ coconut compound; $\mathrm{CE}=$ exhausted compound. Andradina, 2018.

Figura 3. Massa seca da parte aérea (DMAP) do pimentão cultivado em substratos com diferentes compostos orgânicos para produção de mudas. $\mathrm{CC}=$ Composto de $\mathrm{coco} ; \mathrm{EC}=$ Composto exaurido. Andradina, 2018.

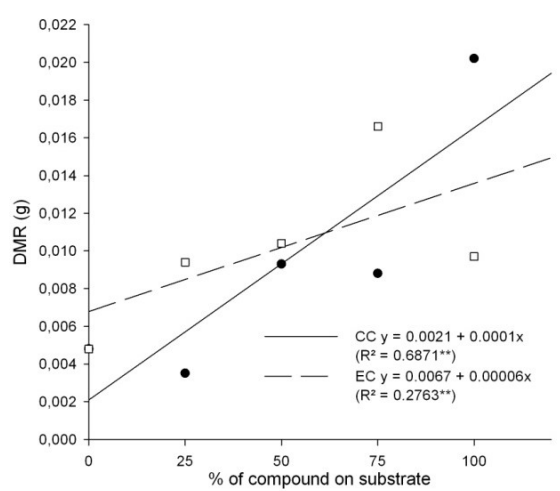

Figure 4. Dry mass of root (DMR) of peppers sown in substrates with different organic compounds to production of seedlings. $\mathrm{CC}=$ coconut compound; $\mathrm{CE}=$ exhausted compound. Andradina, 2018. Figura 4. Massa seca de raiz (DMR) do pimentão cultivado em substratos com diferentes compostos orgânicos para produção de mudas. $\mathrm{CC}=$ Composto de coco; $\mathrm{EC}=$ Composto exaurido. Andradina, 2018.

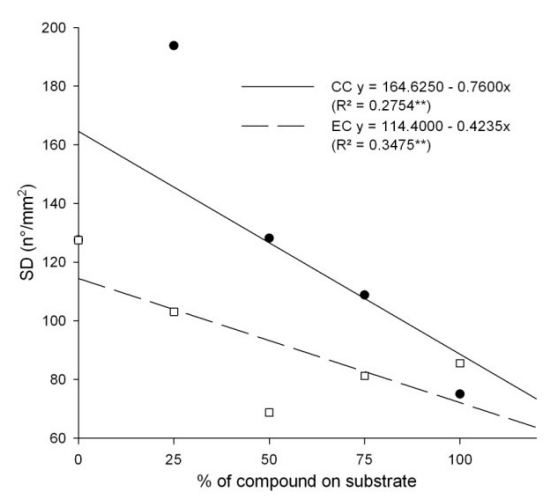

Figure 5. Stomatal density (SD) of abaxial surface of peppers sown in substrates with different organic compounds to production of seedlings. $\mathrm{CC}=$ coconut compound; $\mathrm{CE}=$ exhausted compound. Andradina, 2018.

Figura 5: Densidade estomática (SD) da epiderme abaxial do pimentão cultivado em substratos com diferentes compostos orgânicos para produção de mudas. $\mathrm{CC}=$ Composto de coco; $\mathrm{EC}=$ Composto exaurido. Andradina, 2018.

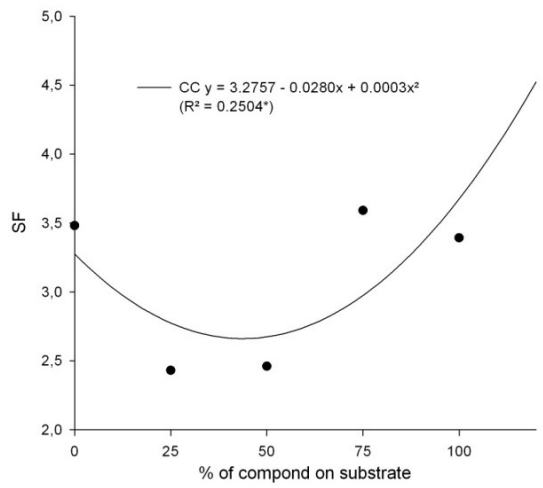

Figure 6. Stomatal functionality (SF) of peppers sown in substrates with different organic compounds to production of seedlings. $\mathrm{CC}=$ coconut compound; $\mathrm{CE}=$ exhausted compound. Andradina, 2018. Figura 6. Funcionalidade estomática (SF) do pimentão cultivado no substrato fibra de coco para produção de mudas. $\mathrm{CC}=$ Composto de coco; EC= Composto exaurido. Andradina, 2018.

\section{DISCUSSION}

The availability of nutrients in initial phases of peppers seedlings was a limiting factor to the growth of aerial part (LI et al., 2018; ABID et al., 2016). It can be proved with the coconut fiber compound, which presented lowest nutritional values (Table 1). That way, seedlings cultivated in exhausted compound presented higher values presented greater height, since they had more nutrients availability. However, high levels of the compound impaired the development, once by elevating the amount of salt in the soil solution, its electrolytic and osmotic capability increase, entailing the loss of water by the seedlings (EPELDE et al., 2018; HOU et al., 2017).

Therefore, concentrations above $70 \%$ harmed the development of the vegetal, that may be amplified with the presence of microorganisms, in which an elevated nutrients cycling were performed, being available in high concentrations in substrate (ZUO et a., 2018; PANDEY et al., 2017).

The number of leaves was also influenced for the greater availability of nutrients in substrate of exhausted compound, similarly with $70 \%$ in its composition (Figure 2). A higher number of leaves promote an increase in photosynthesis rate, entailing a bigger concentration of dry mass in aerial part (Table 1) (Figure 3), that way, a positive correlation between the parameters, as Table 4 shows. The growth of aerial part, occurred due to the higher concentrations of organic compounds in substrate, may influenced the development of roots (Figure 4), since the higher amount of light, proved by the correlation between the dry mass parameters (Table 4), allowed the seedling exploring the substrate in which were inserted, guarantying a greater assimilation of nutrients (MONTEIRO NETO et al., 2016; BATISTA et al., 2016).

These nutrients were available in a bigger amount to leaves, developing fundamental roles in physiological process of the plants and even leading to a morphological interference in vegetal tissues (SANES et al., 2013). By elevating the concentration of organic compounds in substrate of pepper, the stomata density was reduced (Figure 5), demonstrating a negative correlation between the parameters (Table 4). However, these results demonstrates that even diminishing the number of stomates in the abaxial 
face of pepper leaves, the plant' growth was not impaired, it may occurred due to a higher efficiency on its photosynthetic process because of the great concentration of nutrients in its substrates (MINER et al., 2017; CEGLIE et al., 2015).

Stomatal density is directly linked to assimilation rate of $\mathrm{CO}_{2}$ by the leaves, which, due to the elevation in its amount, may impairs the stomata functionality, since they present a relation in opening of the stomata cleft (LI et al., 2017). That way, the higher number of stomates may influenced its function (Figure 6) just in coconut fiber compound.

The higher concentration of calcium and potassium (Table 1) did not influenced the stomata functionality, since the pepper displayed a suitable growth. However, it was expected that nutrients would influence in opening and closure of stomatal, once they are directly linked to the action of calcium and potassium pumps in osmotic balance of stomatal cleft cells (PANDEY et al., 2017; FRANKS et al., 2015).

\section{CONCLUSIONS}

It is recommended using $70 \%$ of peaty exhausted in the composition of substrate to the production of pepper seedlings and using $100 \%$ of coconut fiber in the composition of the substrate to the production of pepper seedlings.

\section{REFERENCES}

ABID, W.; MAGDICH, S.; MAHMOUD, I.B.; MEDHIOUB, K.; AMMAR, E. Date palm Wastes Cocomposted Product: An Efficient Substrate for Tomato (Solanum lycopercicum L.) Seedling Production. Waste and Biomass Valorization, v. 9, n. 1, p. 45-55, 2016. DOI: https://dx.doi.org/10.1007/s12649-016-9767-y

BANZATTO, D. A.; KRONKA, S. do N. Experimentação Agrícola. 4. ed. Funep, 2013. 237 p.

BATISTA, R. O.; FURTINI NETO, A. E.; DECCETTI, S. F. C.; VIANA, C.S. Root morphology and nutrient uptake kinetics by australian cedar clones. Revista Caatinga, Mossoró, v. 29, n. 1, p. 153-162, 2016. DOI: http://dx.doi.org/10.1590/1983-21252016v29n118rc

BURNETT, S. E.; MATTSON, N. S.; WILLIAMS, K. A. Substrates and fertilizers for organic container production of herbs, vegetables, and herbaceous ornamental plants grown in greenhouses in the United States. Scientia Horticulturae, v. 208, p. 111-119, 2016. DOI: http://dx.doi.org/10.1016/j.scienta.2016.01.001

CARLQUIST, S. Ecological strategies of xylem evolution. Berkeley: University of California, 1975. 259 p.

CASTRO, E. M.; PEREIRA, F. J.; PAIVA, R. Histologia vegetal: estrutura e função de órgãos vegetativos. Lavras: UFLA, 2009. 234 p.

CEGLIE, F. G.; BUSTAMANTE, M. A.; AMARA, M. B.; TITTARELLI, F. The Challenge of Peat Substitution in Organic Seedling Production: Optimization of Growing Media Formulation through Mixture Design and Response Surface Analysis. Plos One, v. 10, n. 6, p. 1-35, 2015.

DOI: http://dx.doi.org/10.1371/journal.pone.0128600

CORREIA, K.; MICHEREFF, S. Fundamentos e desafios do manejo de doenças radiculares causadas por fungos. In: LOPES, U. P.; MICHEREFF, S. J. Desafios do
Manejo de Doenças Radiculares Causadas por Fungos. Recife: Universidade Federal Rural de Pernambuco, 2018. p. 1-17.

COSTA, J. P. B. M.; OLIVEIRA, F. A.; OLIVEIRA, M. K. T.; SOUZA NETA, M. L.; BEZERRA, F. M. S.; CAVAlCANTE, A. L. G. Produção de mudas de pimentão utilizando fertirrigação. Revista de Ciências Agrárias, Belém, v. 58, n. 3, p. 263-269, 2015. DOI: http://dx.doi.org/10.4322/rca.1882

EPELDE, L.; JAUREGI, L.; URRA, J.; IBARRETXE, L.; ROMO, J.; GOIKOETXEA, I.; GARBISU, C. Characterization of Composted Organic Amendments for Agricultural Use. Frontiers in Sustainable Food Systems, v. 2, p. 1-12, 2018. DOI: https://dx.doi.org/10.3389/fsufs.2018.00044

FRANKS, P. J.; DOHENY-ADAMS, T. W.; BRITTONHARPER, Z. J.; GRAY, J. E. Increasing water-use efficiency directly through genetic manipulation of stomatal density. New Phytologist, v. 207, n. 1, p. 188195, 2015. DOI: https://dx.doi.org/10.1111/nph.13347

HOU, L.; HU, B. X.; QUI, Z.; YANG, H. Evaluating equilibrium and non-equilibrium transport of ammonium in a loam soil column. Hydrological Processes, v. 32, n. 1, p. 80-92, $2017 . \quad$ DOI: https://dx.doi.org/10.1002/hyp.11400

LI, S.; LI, D.; LI, J.; LI, Y.; GUOXUE, L.; ZANG, B.; LI, Y. Effect of spent mushroom substrate as a bulking agent on gaseous emissions and compost quality during pig manure composting. Environmental Science and Pollution Research, v. 25, n. 13, p. 12398-12406, 2018. DOI: https://dx.doi.org/10.1007/s11356-018-1450-3

LI, Y.; LI, H.; LI, Y.; ZHANG, S. Improving water-use efficiency by decreasing stomatal conductance and transpiration rate to maintain higher ear photosynthetic rate in drought-resistant wheat. The Crop Journal, v. 5, n. 3, p. 231-239, 2017. DOI: http://dx.doi.org/10.1016/j.cj.2017.01.001

MEDEIROS, M. B. C. L.; JESUS, H. I.; SANTOS, N. F. A.; MELO, M. R. S.; SOUZA, V. Q.; BORGES, L. S.; GUERREIRO, A. C.; FREITAS, L. S. Índice de qualidade de Dickson e característica morfológica de mudas de pepino, produzidas em diferentes substrates alternativos. Revista Agroecossistemas, Belém, v. 10, n. 1, p. 159-173, $2018 . \quad$ DOI: http://dx.doi.org/10.18542/ragros.v10i1.5124

MINER, G. L.; BAUERLE, W. L.; BALDOCCHI, D. D. Estimating the sensitivity of stomatal conductance to photosynthesis: a review. Plant, Cell \& Environment, Oxford, v. 40, n. 7, p. 1214-1238, 2017. DOI: https://dx.doi.org/10.1111/pce.12871

MONTEIRO NETO, J. L. L.; ARAÚJO, W. F.; VILARINHO, L. B. O.; SILVA, E. S ARAÚJO, W. B. L.; SAKAZAKI, R. T. Produção de mudas de pimentão (Capsicum annuum L.) em diferentes ambientes e substratos. Revista Brasileira de Ciências Agrárias, Recife, v. 11, n. 4, p. 289-297, 2016. DOI: https://dx.doi.org/10.5039/agraria.v11i4a5395

MORTATE, R. K.; ARAUJO, M. M.; LIMA, M. W. P.; BINOTTI, F. F. S. Resposta de mudas de pimentão submetidas à diferentes reguladores vegetais via foliar. Ciência \& Tecnologia: FATEC-JB, Jaboticabal, v. 10, n. 1, p. 57-64, 2018. 
PANDEY, A. K.; SINGH, A.; PRASAD, J.; SINGH, U.; KUMAR, S. Influence of organic manure, on microbiological properties of calcareous soil. Journal of Experimental Biology and Agricultural Sciences, v. 5, n. 6, p. 886-889, 2017. DOI: https://dx.doi.org/10.18006/2017.5(6).886.889

PORTO, T. B.; SOARES, V. N.; REIS, B. B.; ALMEIDA, A. S.; RODRIGUES, D. B.; TUNES, L. M. Parâmetros de crescimento de plântulas de pimentão na semeadura em diferentes substratos. Revista de La Facultad de Agronomía, La Plata, v. 117, n. 1, p. 69-76, 2018.

SANES, F. S. M.; CASTILHOS, R. M. V.; SCIVITTARO, W. B.; VAHL, L. C.; MORAIS, J. R. Root morphology and potassium uptake kinetic parameters in irrigated rice genotypes. Revista Brasileira de Ciência do Solo, Viçosa, v. 37, n. 3, p. 688-697, 2013. DOI: http://dx.doi.org/10.1590/s0100-06832013000300015

SILVA, F. A. S.; AZEVEDO, C. A. V. de. The Assistat Software Version 7.7 and its use in the analysis of experimental data. African Journal Agriculture Resarch, v. 11, n. 39, p. 3733-3740, 2016. DOI: https://dx.doi.org/10.5897/AJAR2016.11522

ZUO, Z.; YANG, L.; CHEN, S.; YE, C.; HAN, Y.; WANG, S.; MA, Y. Effects of nitrogen nutrients on the volatile organic compound emissions from Microcystis aeruginosa. Ecotoxicology and Environmental Safety, New York, v. 161, n. 2, p. 214-220, 2018. DOI: http://dx.doi.org/10.1016/j.ecoenv.2018.05.095 